\title{
Treatment options for osteoporosis and decision making criteria: 2009
}

\author{
Guillermo Ortiz-Luna, MC,(1) Pedro García-Hernández, MC, (2) Juan A.Tamayo-Orozco, MD.(1,3)
}

Ortiz-Luna G, García-H P,Tamayo-Orozco JA.
Treatment options for osteoporosis
and decision making criteria: 2009. Salud Publica Mex 2009;5 I suppl I:SI I4-SI 25.
Ortiz-Luna G, García-H P,Tamayo-Orozco JA. Alternativas de tratamiento para osteoporosis y criterios de decisión: 2009.

Salud Publica Mex 2009;5I supI I:SII4-SI 25.

\section{Resumen}

La osteoporosis se reconoce mundialmente como un problema de salud pública desde hace muchas décadas, principalmente por el impacto global implícito en la atención de las fracturas que ocasiona. Afortunadamente, cada vez contamos con más y mejores estrategias desarrolladas por la OMS para identificar oportunamente a las personas en riesgo de sufrir una fractura; actualmente es posible definir este riesgo para los siguientes diez años. Lo cual, aunado a métodos cada vez más sensibles para establecer diagnósticos definitivos y opciones de tratamiento costo-eficaces para evitar caídas y disminuir significativamente la presentación de fracturas, permite a quien toma decisiones en este problema diseñar y poner en práctica planes de atención sustentados en la mejor evidencia científica, que son motivo de esta revisión. Varios países empiezan a informar un abatimiento del número de fracturas, después de haber establecido programas dirigidos a este fin desde hace 30 años. Contamos con medicamentos que han demostrado su eficacia para abatir la presentación de la primera fractura o de fracturas recurrentes de manera costo-eficiente, estos se pueden dividir para su estudio de acuerdo al mecanismo de acción que los vuelve eficaces.Así, aquellos que frenan la destrucción del tejido óseo se clasifican como anti-catabólicos, los que estimulan la formación de tejido óseo nuevo son anabólicos, los que tienen ambas acciones se conocen como de acción mixta. En todos los casos, el tejido remanente, previamente formado o en vías de destrucción, que se fortalecerá o el tejido de nueva formación, requieren medidas para garantizar que el proceso de minera-

(I) Instituto Nacional de Perinatología, México, DF.

(2) Hospital Universitario "Dr. José Eleuterio González", Monterrey, NL.

(3) Comité Mexicano para la Prevención de la Osteoporosis, AC, México DF. 
management in the near future and which will bring about a decrease in the impact of the problems in Mexico.

Key words: osteoporosis management; diagnosis; treatment; drugs; anabolic; catabolic; mineralization; cost effectiveness; benefit lización suceda normalmente y se genere hidroxiapatita o un compuesto con características similares para que la eficiencia biomecánica del tejido realmente mejore a largo plazo. Esta revisión incluye algunas perspectivas que seguramente mejorarán nuestro manejo de la osteoporosis en el futuro inmediato y que se deberán reflejar en una disminución del impacto de este problema en México.

Palabras clave: osteoporosis; manejo; diagnóstico; tratamiento; drogas; anabólicas; catabólicas; mineralización; costo efectividad; beneficio
$\mathrm{O}$ steoporosis is a major public health problem worldwide due to the socioeconomic impact of related fragility bone fractures. ${ }^{1,2}$ Mexico and Latin America are no exception to the problem of osteoporosis..$^{3-5}$ Although significant progress has been made during the last three decades towards developing strategies, diagnostic methods, and efficient anti-fracture treatments that have significantly enhanced osteoporosis treatment, Mexico is lacking well designed public policy to address this important problem. Other nations have established strategies for identifying osteoporosis risk and treating fractures over the past 30 years. These strategies include highly sensitive case finding strategies linked to well validated clinical guidelines for clinical decision making regarding treatment and resource use, ${ }^{6,7}$ and have resulted in a reduction in the prevalence and incidence of fragility fractures in their aging populations. ${ }^{8-10}$ This paper will review these treatment methods, in the context of their usefulness in the Mexican population; the review will thus be of use to both epidemiologists and clinical professionals.

\section{Brief history of case finding strategies and their impact in bone health worldwide}

By assessing Bone Mineral Density as grams of hydroxyapatite per square centimeter (BMD) through dual, low energy, X-ray bone absorptiometry (DXA) and defining the T-score for each individual's BMD result according to WHO criteria. ${ }^{1}$ Since 1994 the scientific community has been able to classify individuals' BMD result as normal or with a gradient of increased lifelong, relative risk for suffering fragility fractures if nothing is done to avoid them: Osteopenic if the T score is between minus one and minus 2.49 standard deviations from $\mathrm{T}$ and Osteoporotic if it is two and a half standard deviations or more below T. T is determined as the mean plus or minus one standard deviation of the BMD of the normal male or female young adult population 20 to 39 years of age. Soon the diagnostic sensitivity of the $\mathrm{T}$ score determination was improved obtaining information through questionnaires on the individual's risk factors. With this combination, it has become possible to distinguish at least three populations with an elevated lifetime risk for becoming osteoporotic and / or suffering from bone fragility fractures; these populations require different treatment strategies. At-risk groups are: 1) people younger than 35 years of age with lower than normal peak bone mass development, 2) people of both sexes younger than 60 that have both a BMD value classified as osteopenic by WHO criteria and one or more fracture risk factors, but who do not have bone fragility fractures, and 3) Postmenopausal women or men older than 60 with low BMD values, three or more risk factors, and prevalent bone fragility fractures. ${ }^{6}$

The division of those populations at risk for fragility fractures into these subgroups has raised two key questions that will be addressed in this paper: 1) Are preventive interventions cost efficient in younger populations with a high lifetime risk of having a fragility fracture? and 2) Do we have cost efficient therapeutic interventions for populations with a demonstrated, high 10 year risk of having a bone fragility fracture using the new diagnostic tool recently published by WHO named FRAX?7,11,12

Are preventive interventions cost efficient in populations with a high lifetime risk of fragility fracture?

Prevention strategies for osteoporosis and/or bone fragility fractures in younger populations without evidence of current fractures has been the subject of an intense debate that will continue until scientific evidence accrues that demonstrates these strategies to be cost efficient: ${ }^{11,12}$ Why are preventive interventions a matter of such intense debate? Good scientific evidence makes it theoretically reasonable to recommend two kinds of interventions as lifelong preventive measures to stop the 
development of osteoporosis and / or fragility fractures in later life by: 1) optimizing peak bone mass ${ }^{13-19}$ and 2) increasing bone mass. ${ }^{20}$ In this introduction we will briefly concentrate on some details of the two interventions mentioned, and will go into more detail later in this paper. The interested reader will also find more information regarding these issues in other contributions published also in this special number of the journal.

The case of optimizing peak bone mass (PBM). PBM is defined by the moment in which bone mineral accretion stops and reaches its maximum value. This phenomenon is asynchronous throughout the 206 bones of the skeleton, and starts in some anatomical regions as early as at the age of 18 years and involves the whole skeleton between the ages of 35 to 40 years. After PBM is attained, a slow but permanent decrease in BMD begins and will continue until death. Therefore, PBM represents the intact and maximal bone mineral reserve of each person, from which bone loss will happen in a bone mass deteriorating condition.

Although excellent scientific evidence has demonstrated that increasing PBM by $10 \%$ provides $50 \%$ protection against future osteoporosis, ${ }^{1,13-19}$ the challenge is to demonstrate that a public health program designed to improve PBM would decrease the incidence of osteoporosis in the population within 50 years; this would be a very difficult and costly study to perform, and thus has yet to be executed.

The case of drug interventions to improve Bone Mineral Density (BMD) long before the event of the first bone fragility fracture. A similar challenge is to demonstrate the population efficacy of the use of drugs to improve bone mass in people of both sexes before age 60, who have different degrees of osteopenia according to WHO's $\mathrm{T}$ - score criteria and three or more fracture risk factors, without prevalent bone fragility fractures. $11,12,20$

As in the case of improving PBM, excellent scientific evidence demonstrates that various drugs improve bone mass independently of the patient's age and the kind of risk involved. However, the results of the very few studies large enough to estimate the number of cases that must be treated in order to avoid a fracture, have not demonstrated yet that they are cost efficient. ${ }^{20-22}$ The interested reader is referred to special and excellent reviews on this matter in the recent literature as well as in other contributions of this special number of the journal. ${ }^{12-22}$ The rest of this introduction will focus on developing a step by step decision making process in order to answer the second question of this paper.
Do we have cost efficient the rapeutic interventions for populations with demonstrated, high 10 year risk of having a bone fragility fracture?

A simple answer to this question is yes, and we foresee that important developments in drug therapy will be introduced promptly, enhancing our scope to combat this public health problem more efficiently, which is the essential point of this review. This question relates to the existence of cost effective therapeutic interventions for populations identified with the new diagnostic tool recently published by WHO named FRAX., ,11,12

Therefore it is convenient to briefly review the recent introduction of the FRAX by WHO. Improving case finding strategies of osteoporosis in different populations was a task adopted by the expert panel of WHO since 1994. After introducing the T score determination ${ }^{1}$ they continued reviewing the published evidence from several large, long term international epidemiological cohort studies on the most important risk factors associated with bone fragility fracture. These factors were identified and combined in a mathematical model with body mass index, sex, ethnicity, femoral BMD and a few other socioeconomic criteria in order to determine the absolute 10 year fracture risk and the burden for a particular case. FRAX incorporates all these factors in a computerized format that improves the diagnostic sensitivity of the WHO criteria published in 1994 and defines who has a significant and absolute high risk of presenting a fragility fracture in the next 10 years. ${ }^{23}$

FRAX identifies the fracture risk of a person at the primary health level, allowing a general practitioner to use it. Thus a new decision making scenario has arisen, in which the primary healthcare practitioner needs to confirm that a high risk individual has osteoporosis and therefore needs to choose and follow a cost effective antifracture treatment. In order to: a) Establish the presence of osteoporosis, b) Choose between the different therapy options and c) Be cost effective.

The medical practitioner will need additional information derived from well validated diagnostic methods that we will briefly review. In our step-by-step action plan to treat the osteoporotic patient, we will not discuss how to define whether the patient has the disease -it is beyond the scope of this review-but once it is confirmed that the patient has it, it is essential to define: 1) Baseline BMD at the lumbar spine and in the whole proximal femoral region, and if possible bone quality (vide infra). 2) The kind of bone remodeling present reflecting the functional state of bone tissue. 
The advances in diagnostic methodology that we will review are those that yield the best results for the care of individual patients, because they allow the clinician to follow-up the changes induced by treatment either with single drug schemes, combination and even sequential regimes to be reviewed in the following sections of this paper and are the result of enhanced knowledge of the cellular and molecular mechanisms involved in normal bone mass remodeling, deterioration and restoration. This knowledge has also been instrumental in the development of new drugs, targeted at increasing the efficacy of specific mechanisms of bone remodeling to restore normal bone quality. ${ }^{24-41}$

The advantages of having new case finding strategies like FRAX, diagnostic tests for determining the activity of bone remodeling, and other imaging procedures useful for choosing the optimal treatment regime and defining the clinical outcomes to be expected are extensively discussed elsewhere. ${ }^{40,42-44}$ In this paper the available treatments will also be analyzed based on their efficacy from the moment the treatment decision is made, throughout the follow up period.

\section{Step by step action plan to treat patients with osteoporosis and significantly elevated 10 year risk of fracture}

Our action plan starts defining an astounding fact: "During the first year of treatment the most effective antifracture strategy is to prevent falls", ${ }^{45}$ drugs with proven anti-fracture efficacy must be started simultaneously with the anti-fall program, it is necessary to consider that it will take any available drug at least six months to restore the remnant bone tissue and to develop new bone-forming units that will protect the skeleton in the long term. In order to achieve these important goals, a step-by-step decision making process needs to be followed including the actions listed below as well as the way to evaluate them:

1. Define the pre-treatment patient's BMD values and if possible consider measuring the bone quality of the remnant bone mass in the anatomical regions that are currently at fracture risk (baseline values).

2. Classify the bone remodeling activity as one of the following patterns: A) High bone turnover rate, characterized by predominance of destruction activity mediated through osteoclasts/osteocytes. B) Normal bone turnover rate or C) Low bone turnover.

3. Depending upon these design criteria: A) Anti-fall strategies to prevent fractures in the short term, while bone strength is improved in the long term with drugs; keeping in mind that a minimum of six months is required with the most potent of them. B) Choose an effective, scientific based drug regime. C) Define the treatment targets and the time intervals at which their results will be evaluated. At these subsequent points in time, decide to continue or to change therapy options based on the treatments' efficacy.

All of the above said, we will continue this important section of our suggested step by step decision making process, analyzing the role of baseline BMD values and the characteristics of the residual bone mass present before treatment, namely quality and functionality of bone tissue, as gold standard criteria to evaluate the response to the selected treatment:

1. Define pre-treatment patient's BMD values and if possible consider measuring bone quality of the remnant bone. The yearly increase in BMD is small, and is difficult to determine precisely in clinical densitometry laboratories as their high in vivo variation coefficient is greater than the drug's induced increase in BMD (see below); therefore it is convenient to measure it not earlier than one year and not later than two years after pharmacological treatment is started.

What is the role of baseline BMD values and if available, the bone quality of the residual bone mass in anatomical regions that are currently at risk of fracture, as baseline values to be compared with the changes induced by treatment?

Several lines of evidence have shown that the initial values of BMD alone are insufficient criteria to decide who should receive treatment. The same observation can be made regarding changes in BMD to follow up the results of a therapeutic regime and to define who is responding. ${ }^{43,44}$

The lack of BMD sensitivity to decide who should receive treatment and with what kind of drug, can be explained simply by stating that having low BMD at any anatomical site may not be due only to osteoporosis, but to a number of other clinical conditions such as hypodense osteomalatias or osteodystrophies, which require different diagnosis and therapeutic approaches and imply different risks of developing fragility fractures. ${ }^{47-51}$

On the other hand, the use of the change in BMD as a criterion to evaluate the response to treatment is not as useful as may be expected. Large, well designed studies on a wide variety of drug treatments, with proven antifracture efficacy have shown that induced increases in 
BMD are very small, meaning that they reach an increase between 2 and maximum $6 \%$ per year above baseline values, an amount of bone mineral difficult to measure in the conventional, clinical bone densitometry laboratory that runs with a variation coefficient in vivo of $2 \%$ or more. And although the increase in BMD is undoubtedly part of the restoration of bone mass, it is not the only change related to the anti-fracture efficacy of these treatments. ${ }^{20-22,25,30,52}$ Possible explanations of this lack of sensitivity of BMD for this particular purpose, besides the technological issue just cited, are related to the fact that most treatment schemes also improve muscle function, nerve reflexes and other non-BMD factors, that also have protective anti-fracture effects. ${ }^{52,53}$

In addition to the reasons just reviewed, that explain in part why BMD is not as useful as expected in determining the success of a treatment regime, there are two other major concerns regarding the characteristics of the already existing bone, to be taken in consideration before treatment is started and that will define the success of treatment: the quality of the remnant bone tissue and its functional characteristics. ${ }^{38-41}$

We will begin by pointing out that the goal of any anti-fracture treatment starts by improving the quality and functionality of the pre-existing, remaining bone reserve, whether it is healthy or not.

If one look at bone surfaces in an osteoporotic skeleton, they will show different stages (asynchronous) and kinds of structural alterations (asymmetrical), going from trabecular thinning to trabecular loss and connectivity. There will be zones of cortical tunneling, widening of endosteal diameters and debilitation of the cortical width, that can be assessed by different imaging procedures as the Ultrasound transmission or attenuation (BUA and SOS), peripheral computed tomography, microanalysis magnetic resonance, and dynamic mineralized bone histomorphometry. ${ }^{43,44}$

Bone quality will also depend on the materials deposited when induced remodeling takes place, their composition relates to the type and organization of bone matrix as well as the kind of crystals, and mineral maturation in the bone matrix, i.e.: true, efficient hydroxyapatite $v s$. false, inefficient apatites (fluoride or another mineral matrix/organizations).

2. Classify the bone remodeling activity as one of the following patterns: A) High bone turnover rate, characterized by predominance of destruction activity mediated through osteoclasts / osteocytes. B) Normal bone turnover rate or C) Low bone turnover. In the previous step we did review the importance of bone quality of the remnant bone tissue in the osteoporotic skeleton, let's continue analyzing the functional characteristics of the already existing bone, that depend on the kind of remodeling activity present and the minerals deposited in the mineralization front. The minute-to-minute, as well as the long-term, mineral exchange between bone and extra cellular fluid will also be affected by the homeostasis integrity of bone mineral metabolism. ${ }^{41}$

A) As stated at the beginning of this step, if there is a high bone turnover rate, bone deterioration takes place when destruction activity through osteoclasts/osteocytes prevails over bone formation activity. The left side of figure 1 depicts this situation. The duration of this disequilibrium determines the amount of bone mass lost. In this situation, administration of an anti-catabolic drug will be very effective, as shown in the right side of figure 1 . It is very apparent that after a potent anti-destructive drug is administered in this condition, where both cellular activities are increased, bone destruction is acutely depressed and this is sustained while the drug is administered during three years. Notice that bone formation is

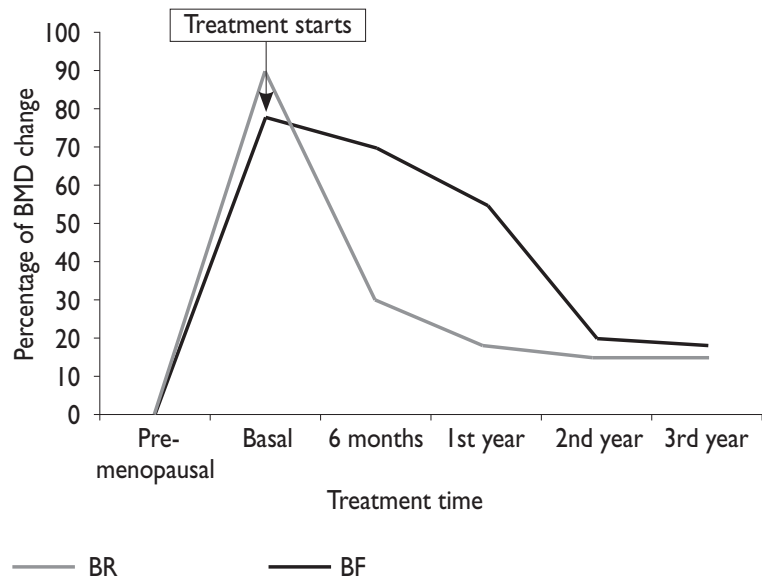

Figure I. The ACtivities OF Bone Forming (BOLd LiNe, BF) AND BONE RESORBING UNITS (THIN LINE, BR) ARE DEPICTED BEFORE TREATMENT, SHOWING A PREDOMINANCE OF BONE RESORBING ACTIVITY, LEADING TO BONE DESTRUCTION AND LOWERING BONE MASS. WHEN TREATMENT STARTS AT BASAL TIME, THERE IS A VERY PROFOUND REDUCTION OF BONE RESORPTION (THIN) FOLLOWED BY A VERY SLOW RETURN OF BONE FORMATION TO A SEMI COUPLED STATE AT THE SECOND YEAR OF TREATMENT. SEE TEXT FOR DETAILS 
uncoupled immediately after the administration of the anti-destructive drug, and slowly returns almost to the coupled state after the second year of treatment, remaining above bone destruction, thus favoring bone gain. The increase in BMD will be equal to the amount of bone tissue lost during the pre-treatment phase of the disease, in other words to the amount of bone destroyed. Therefore, administering an anti-destructive drug will be useful while the activity of bone turnover remains unbalanced, and bone formation prevails; the benefit will stop when bone formation becomes equal to bone destruction, a fact that is generally observed after 24 months of effective antidestructive therapy with bisphosphonates, potent anti-catabolic agents.

$\mathrm{B}, \mathrm{C})$ There is normal or low bone turnover. This situation is commonly seen when patients have received anti-destructive treatments and/or when the patient is approaching old age. These patients will benefit from a bone forming agent, a drug that will be considered anabolic for bone tissue (figure 2). These concepts are quite important in clinical practice because they provide the basis to recapture the interest raised theoretically 20 years ago in sequential treatment schemes, adjusted according to the periodical investigation of bone turnover activity. ${ }^{55}$

3. Depending upon these design criteria: A) Anti-fall strategies to prevent fractures in the short term, while bone strength is improved in the long term with drugs, keeping in mind that a minimum of six months is required with the most potent of them. B) Choose an effective, scientific based drug regime. C) Define treatment targets and time intervals at which their results will be evaluated. At these subsequent time points, decide whether to continue or to change therapy options based on treatment efficacy.

A) Design anti-fall strategies to prevent fractures in the short term, while bone strength is being improved. Before treatment is started, the integrity of residual bone mass is affected throughout the skeleton; improving bone quality and strength will take at least six months to be protective against new fractures. ${ }^{56}$ Thus, it is very important to perform a careful evaluation of the patient's musculoskeletal stability and design a program to prevent falls, the most common cause of fragility fractures in the elderly. ${ }^{57}$

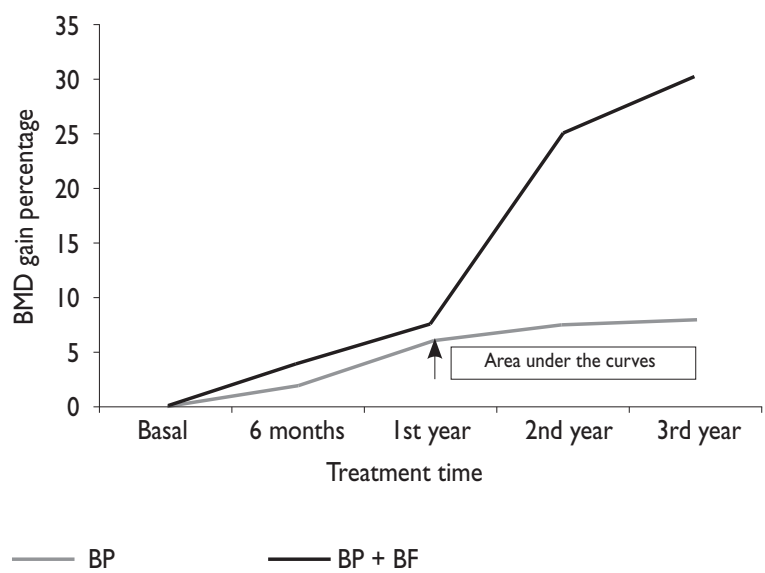

Figure 2. After two years of Biphosphonate treatment (BP) BMD APPROACHES A PLATEAU IN ABOUT 7\% GAIN. IN THE RED LINE, AFTER ONE YEAR OF BP TREATMENT, AN ADDITIONAL BONE FORMING AGENT (BF) IS ADDED, A STRIKING GAIN IN BMD IS ACHIEVED AND SUSTAINED WHILE TREATMENT IS MAINTAINED. THE AREA UNDER BOTH CURVES (BLUE AND RED) DEPICTS THE BMD GAINED

B) Choose an effective drug regimen. Drugs available to treat osteoporosis fall into the following categories: ${ }^{42-44} 1$ ) Anti-catabolic: drugs that decrease bone destruction by restoring all hyperactive bone reabsorbing cells to their normal state (Osteoclasts and/or osteocytes), independently of the intrinsic mechanism of drug action. 2) Anabolic: drugs that augment the bone forming activity through the osteoblast related cell lineage. 3) Mixed or dual action: agents that have both effects. ${ }^{42-44}$ Regardless of the kind of drug treatment used to restore deteriorated bone to health, there is general agreement on the need of Vitamin D3 and dietary mineral supplementation in order to guarantee normal mineralization of already existing osteoid seams or of newly formed bone tissue. ${ }^{46-52}$ Maturation of normal hydroxyapatite salts and/or other apatites upon the osteoid seams with equivalent biomechanical properties is needed to restore the functional integrity of the bone's micro. ${ }^{50,51}$ A related key concern is to demonstrate the kind of bone tissue acquired after treatment with the different drugs available in clinical use in. ${ }^{38-41,54}$

C) Define the treatment targets and the time intervals at which their results will be evalu- 
ated. At these subsequent time points, decide to continue or to change therapy options based on treatment efficacy. Considering that restoration of the remnant bone reserve will take at least one year, a fracture that occurs during the first year of follow up does not represent treatment failure. Time intervals as well as biochemical markers of bone turnover and determination of changes in BUA or SOS attenuation, microanalytical MRI, peripheral PCT or BMD should be designed according to the individual conditions and / or to follow, if available, an internationally accepted clinical guideline.

\section{Drug interventions available in Mexico}

We will now address some practical issues associated with the drugs that are proven to be effective against fracture and are available in Mexico.

1. Drugs acting predominantly as anti-catabolic or anti-destructive agents: These are represented in the Mexican scenario by a) Estrogens, b) Selective Estrogen receptor modulators and c) Bisphosphonates. We will briefly review the highlights of each agent.

a) Estrogens: The anti-fracture efficacy of estrogens alone or combined in different regimes of hormone replacement therapy (HRT) is demonstrated but controversial. While their effect in the normalization of bone remodeling as well as in BMD is well demonstrated, it is lost as soon as from the first month after discontinuation. At that time, the activity of bone turnover increases with a predominance of the destruction of bone by the osteoclasts and osteocytes. Resembling the active phase of post menopausal bone loss similar to that illustrated in figure 1 , and undoes the protective effects of the HRT. ${ }^{58}$

b) Selective Estrogen Receptor Modulators: The role of SERMS is also well documented: they normalize and stabilize bone turnover in the early postmenopausal period. Raloxifene is the only SERM available in Mexico, and its antifracture efficacy makes it an excellent option both in the early postmenopausal period as well as in elderly women. However, as in the case of HRT, the protective effect of SERMS on bone mass is lost as soon as one month after discontinuation of treatment. ${ }^{59,60}$

c) Bisphosphonates: The anti-fracture efficacy of bisphosphonates is well documented at vertebral and most non-vertebral skeletal sites; its effects against proximal femur fractures are the best studied. ${ }^{61,62}$ There are several bisphosphonates of different potencies available, designed to improve tolerance and long term adherence. ${ }^{63-73}$ These drugs evolved from daily treatments to drugs administered weekly, monthly or every six to twelve months. One such drug, alendronate, incorporates $25 \mathrm{OH}$ Vitamin D3, assuring that the patient receives his/ her weekly recommended amount of this steroid, which is important for promoting a positive mineral balance and improving bone matrix mineralization. This is the only bisphosphonate that has been shown to have a permanent protective anti-fracture effect after discontinuation following a two year period of administration. ${ }^{63,74}$ Almost all of the bisphosphonate preparations available today are effective in reducing fracture risk by 14 to $50 \%$ after six months of continuous treatment, and provide more than $60 \%$ protection against fractures if treatment is successfully followed for more than 18 months. ${ }^{61-63}$ These results occur irrespective of the administration scheme, be it orally at daily, weekly or monthly intervals or intravenously every six months or once a year.

Table I provides a summary of the anti-fracture efficacy of anti-destructive agents. Caution must be taken after the second year of administration of such a regime in order to avoid fatigue damage; after four months of administration, the biochemical markers of bone turnover should be examined. ${ }^{54}$

From a public health perspective, compliance represents a problem for treatment using bisphosphonates. The least favorable effect that would justify an investment in population-level treatment with biphosphonates would be to decrease the fracture incidence by a minimum of $40 \%$ in each individual. The available evidence demonstrates that an effective six-month period is the minimum timeframe needed to attain such an effect. Therefore, those regimes that facilitate compliance for six months or more, such as injections or monthly dosages, may be superior to daily or weekly orally administered options. ${ }^{21,22}$

Finally, considering that the fracture risk is so high in the population selected by FRAX, the number of cases that need treatment to prevent a fracture is cost effective, making this treatment a very good choice. Studies have found that 40 to 60 patients need to be treated to prevent one vertebral or proximal femur fracture. This is 
Table I

REPORTED RESULTS ON THE EFFECTS OF DIFFERENT TREATMENT OPTIONS ON NON-VERTEBRAL BONE FRACTURES

\begin{tabular}{|c|c|c|c|c|c|}
\hline Drug and dosage & Study population & Length of treatment & $n$ & Relative risk IC 95\% & (reference \#) \\
\hline Alendronate $>10 \mathrm{mg} /$ day & $\begin{array}{l}\text { Osteoporotic } T<2.0,7 \% \text { of data collected from a } \\
\text { prevention study }\end{array}$ & I-4.5 & 3723 & $0.5(0.38,0.69)$ & (I) \\
\hline Alendronate $>5$ mg/day & $\begin{array}{l}\text { Osteoporotic-Cranney }(>10 \mathrm{mg} / \text { day) plus FIT ( } \mathrm{Vx} \mathrm{Fx} \\
\text { or femoral T score }<2.5)\end{array}$ & I-4.5 & 7381 & $0.66(0.57,0.77)$ & Meta analysis $(I, 16)$ \\
\hline $\begin{array}{l}\text { Hormone Replacement } \\
\text { Theraphy }\end{array}$ & $\begin{array}{l}\text { Osteoporotic and non osteoporotics (BMD was not } \\
\text { an acceptance requisite) }\end{array}$ & $1-7$ & 31333 & $0.75(0.70,0.8 \mathrm{I})$ & Meta analysis $(1,2,3)$ \\
\hline Ibandronate & Osteoporotics $(\mathrm{Vx} F \mathrm{~F}$ and $\mathrm{T}<2.0)$ & 3 & 2946 & $\begin{array}{c}\text { I.II (ns) daily I.09 } \\
(0.79,1.06)\end{array}$ & (4) \\
\hline Raloxifene & $\begin{array}{l}\text { Osteoporotics }(\mathrm{V} x \mathrm{Fx} \text { or } \mathrm{Vx} T<2.5 \\
\text { or Femoral neck } T<2.0)\end{array}$ & 3 & 6961 & $0.91(0.79,1.06)$ & $(1,18)$ \\
\hline $\begin{array}{l}\text { Resindronate } 2.5 \\
\text { or } 5 \mathrm{mg} / \text { day }\end{array}$ & $\begin{array}{l}\text { Osteoporotic (six studies) or Age > } 80 \text { years with risk } \\
\text { factors for falls (one study); } 0.9 \% \text { of data are from } \\
\text { a prevention study }\end{array}$ & 3 & 12958 & $0.73(0.61,0,87)$ & (I) \\
\hline Resindronate $5 \mathrm{mg} /$ day & Osteoporotics & 3 & 8000 & $0.68(0.53,0.87)$ & (I) \\
\hline
\end{tabular}

a highly efficient cost/ benefit ratio if one considers that direct cost of a single proximal femoral fracture is in the range of 37000 Mexican pesos, while the most expensive anti-catabolic treatment available costs a mean 12000 Mexican pesos per year (2006 USD dollar parity). ${ }^{75}$

2. Drugs acting as anabolic, bone forming or dual action agents: Parathyroid hormone has long been used as a therapeutic agent against osteoporosis based on the classic experimental demonstration in humans that a daily low dose pulse of PTH, by daily morning administration of one gram neutral phosphate, increases bone mass if it is followed in a sequential scheme by the administration of Calcitonin. ${ }^{76-78}$ These studies were the first clinical evidence demonstrating anabolic effects with this low dose polypeptide induction. They were published two decades ago, before the development of the new generation of synthetic PTH analogues like teriparatide, which has proven anti-fracture efficacy sooner than the most potent anti-catabolic compounds; the anti-fracture effect of the former is also evident when administered in combination therapeutic regimes. ${ }^{7879}$ Daily, low dose PTH administration or carefully controlled induction is a gold standard anti-fracture compound nowadays.

Dual-acting drugs like strontium ranelate are raising hopes for the efficacy of single drug or combination regimes that will render better long term results improv- ing the bone quality and strength achieved, ${ }^{80-83}$ they are available in Mexico, are well tolerated and considering their cost, do represent a very good option.

The quality of bone tissue formed by these anabolic compounds is normal. Therefore, they do represent a great option to start treatment in low or normal bone remodeling patients or in those treated with an anticatabolic drug once bone remodeling activity reaches equilibrium, avoiding the inconvenience of fatigue damage.

Patient compliance is the single most important factor to be considered when choosing between these two, daily administered medications. Teriparatide must be refrigerated and injected subdermally daily, factors that hamper compliance and raise the long-term cost of the treatment. While strontium ranelate does not have these drawbacks, it must be dissolved in liquid and taken on an empty stomach one or two hours before meals, factors that adversely influence compliance with this drug regimen.

3. Combination therapies: On a long-term basis, optimal anti-fracture effects can be obtained by prescribing a carefully orchestrated sequence of anti-catabolic and bone forming agents. ${ }^{77,79}$

4. The Pandemic of $25 \mathrm{OH}$ Vitamin D3 deficiency, insufficiency or inefficiency: Quite recently, several groups have called attention to an old and very well known requisite for bone mineralization, the availability of enough Vitamin D3 and its active 
Table II

EFFECTS OF TREATMENT ON PROXIMAL FEMUR FRACTURE RISK

\begin{tabular}{|c|c|c|c|c|c|}
\hline Drug and dose & Treated population & Length of treatment & $n$ & Relative risk IC $95 \%$ & (reference \#) \\
\hline Alendronate $510 \mathrm{mg} /$ day & Osteoporotics (vertebral fx o $T<2.5$ ) & |-. .4 .5 & 6804 & $0.45(0.28,0.7 \mathrm{I})$ & ( 1$)$ \\
\hline Alendronate $510 \mathrm{mg} /$ day & Osteoporotics- (vertebral fractures or $T<2 ., 0$ ) & I-4.5 & 9023 & $0.55(0.36,0.84)$ & (I) \\
\hline Alendronate $>5 \mathrm{mg} /$ day & $\begin{array}{l}\text { Osteoporotics and not osteoporotics (some data } \\
\text { from prevention studies) }\end{array}$ & I-4.5 & II 808 & $0.63(0.43,0.92)$ & (2) \\
\hline Alendronate $>10 \mathrm{mg} /$ day & $\begin{array}{l}\text { Osteoporotics ( } T \text { store }<2.0 \text { ), } 7 \% \text { of data from } \\
\text { prevention studies }\end{array}$ & I-4.5 & 3723 & $0.45(0.18,1.13)$ & (2) \\
\hline $\begin{array}{l}\text { Hormone replacement } \\
\text { therapy }\end{array}$ & $\begin{array}{l}\text { Osteoporotics and not osteoporotics (BMD was } \\
\text { not a requirement) }\end{array}$ & $5-7$ & 27347 & $0.64(0.49,0.84)$ & Meta analysis $(3,4)$ \\
\hline Ibandronate & Osteoporotics (vertebral $\mathrm{fx}$ and Tscore $<2.0$ ) & 3 & 3929 & $\begin{array}{l}I .50(0.42,5.33) \\
2.76(0.88,8.7 I)\end{array}$ & (5) \\
\hline Raloxifene & $\begin{array}{l}\text { Osteoporotics (vertebral fx or vertebral T score } \\
<2.5 \text { or femoral } \mathrm{T}<2.0 \text { ) }\end{array}$ & 3 & 7705 & I.I $(0.6, I .9)$ & (9) \\
\hline Risedronate & $\begin{array}{l}\text { Osteoporotic (three studies) or age }>80 \text { with risk } \\
\text { factors or fall (one study) }\end{array}$ & 3 & 13015 & $0.74(0.58,0.94)$ & Meta analysis $(6,7,8)$ \\
\hline
\end{tabular}

metabolites to guarantee positive mineral body balance and adequate bone mineralization. ${ }^{42-52}$

It has been demonstrated that although they may have normal reference values for Vitamin D3, most osteoporotic patients, and more significantly those who suffer a fragility fracture, have levels of $25 \mathrm{OH}$ Vitamin D3 (calcidiol) insufficient to sustain normal parathyroid function. ${ }^{52,74}$

Therefore it is now recommended to measure patients' $25 \mathrm{OH}$ Vitamin D3 serum levels in combination with total and / or ionized serum calcium and intact PTH concentration, in order to improve bone quality and strength if low or inefficient Vitamin D3 and high intact PTH serum levels are present. ${ }^{52}$ In table II we analyze some data from the literature regarding the anti-fracture efficacy in proximal femur fracture of the drugs available in Mexico.

It is convenient to briefly analyze fatigue damage of bone induced by bisphosphonates and its prevention: During the last decade, the generalized use of different bisphosphonates on a long-term basis has raised the possibility of inducing fatigue damage in bone secondary to decreased or blunted normal bone remodeling. Most anti-catabolic agents of the kind literally stop bone destruction, regardless of whether it was involved in a normal BMU remodeling or in a pathological one. Scientific evidence suggests that stopping the removal of old, damaged bone by normal physical activity (micro trauma) with bisphosphonates impede the renewal of these bone sections; the bone thus becomes old and will develop structural damage (fatigue) over time. This situation leads to structural inefficacy and paradoxically increases fracture risk, beginning after five years of normal osteoclastic, osteocytic activity blockade in normal BMUs. ${ }^{38-44,54}$ In order to counteract this situation one must consider avoiding administration of anti-catabolic drugs without the evidence of high bone turnover activity or if there is no routine access to these determinations, never administer a bisphosphonate for more than three years without confirmation of bone remodeling activity, which is always feasible throughout Mexico.

New drug development: Physiologically oriented anti-catabolic agents, like demosunab, that target the OPG-RANK-L complex, and inhibitors of the different cathepsins that regulate the coupling between bone resorptive and bone forming cells, are currently in phase III clinical trials. Bone formed under these more physiologically acting therapies is expected to be of normal quality and strength. ${ }^{85-87}$

\section{Conclusions}

Mexico, like most countries worldwide, faces an extraordinary opportunity to fight fragility fractures in the population at high risk for suffering a fragility fracture in the next 10 years. It is feasible because Mexico has access to FRAX, and although there is no Mexican data base available, the Hispanic data base can be used while 
the Mexican one is validated. There are facilities to determine BMD in the lumbar spine and proximal femur in almost all major cities of the country and the number of peripheral equipment for BMD screening is growing. Moreover, the drugs proven to be useful as anti-fracture agents are available and there is growing awareness among the population that this is a preventable complication with better quality of life expectancy.

This is an opportune moment to positively impact our health system with an effective case finding strategy undertaken in high risk populations, coupled with an early intervention clinical guideline strategy based on the best available scientific evidence, to lower the global burden of osteoporosis and metabolic bone disease. It is expected that such an intervention would both lower the incidence of fragility bone fractures and decrease the number of osteoporotic patients in the coming decades. ${ }^{3-5}$

\section{References}

I.World Health Organization. Assessment of fracture risk and its application to screening for postmenopausal osteoporosis. Report of a WHO study group. WHO Technical Report Series. 1994;No 843. 2. Johnell O, Kanis JA. An estimate of the worldwide prevalence and disability associated with osteoporotic fractures. Osteoporos Int 2006; 17(12): 1726-1733.

3. Clark P, Lavielle Pilar, Franco-Marina F,Ramirez E, Salmerón J, Kanis JA, et al. Incidente rates and life-time risk of hip fractures in Mexicans over 50 years of age: a population-based study. Osteoporosis Int 2005; 16: 2025-2030.

4. Clark P, Cons-Molina F, Deleze M, Ragi S, Haddock L, Zanchetta JR, et al. The prevalence of radiographic vertebral fractures in Latin American countries: the Latin American Vertebral Osteoporosis Study (LAVOS). Osteoporos Int 2008; 19(3):269-276.

5. Morales-Torres J, Gutiérrez-Ureña S, et al. The burden of osteoporosis in Latin America. Osteoporos Int. 2004;15:625-632.

6. Cummings SR, Melton LJ. Epidemiology and outcomes of osteoporotic fractures. Lancet 2002; 359: I76I-I767.

7. Kanis JA, Johnell O, Oden A, Dawson A, De Laet C, Jonsson B. Ten year probabilities of osteoporotic fractures according to $B M D$ and diagnostic thresholds. Osteoporos Int 200 I; I2(I2):989-995.

8. Cooper C, Campion G, Melton LJ. Hip fractures in the elderly: a worldwide projection. Osteoporos Int 1992; 2(6):285-289.

9. Kannus P, Niemi S, Parkkari J, Palvanen M,Vuori I, Jarvinen M. Nationwide decline in incidence of hip fracture.J Bone Miner Res 2006; 2I(I2):1836-1838.

10. Jaglal SB, Weller I, Mamdani M, Hawker G, Kreder H, Jaakkimainen L, et al. Population trends in BMD testing, treatment, and hip and wrist fracture rates: are the hip fracture projections wrong? J Bone Miner Res 2005; 20(6):898-905

II. KM, Nicholson GC,Watts J], Pasco JA, Henry MJ, Kotowicz MA, Seeman E. Half the burden of fragility fractures in the community occur in women without osteoporosis. When is fracture prevention cost-effective? Bone 2006;38(5):694-700
12. Siris E, Chen Y-T,Abbott T, et al. Bone mineral density thresholds for pharmacological intervention to prevent fractures. Arch Intern Med 2004; 164: I 108-III2.

I3. Bonjour JP, Theintz G, Law F, Slosman D, Rizzoli R. Peak bone mass. Osteoporos Int 1994;4 Suppl 1:7-13.

I4. Bonjour JP, Chevalley T. Pubertal timing, peak bone mass and fragility fracture risk. BoneKey-Osteovision. 2007; 4:30-48. Available in: http://www. bonekey-ibms.org/cgi/content/full/ibmske; $4 / 2 / 30$.

I5. Gilsanz V, Gibbens DT, Carlson M, Boechat MI, Cann CE, Schulz EE. Peak trabecular vertebral density: a comparison of adolescent and adult females. Calcified tissue international 1988; 43(4):260-262. 16. Davis JW, Grove JS, Ross PD, Vogel JM, Wasnich RD. Relationship between bone mass and rates of bone change at appendicular measurement sites.J Bone Miner Res 1992; 7(7):719-725.

17. Buchs B, Rizzoli R, Slosman D, Nydegger V, Bonjour JP. Densité minérale osseuse de la colonne lombaire, du col et de la diaphyse fémoraux d'un échantillon de la population genevoise. Schweiz Med Wochenschr 1992; |22(30): | | 29- | | 36.

18. Melton LJ,Atkinson EJ, Khosla S, Oberg AL, Riggs BL. Evaluation of a prediction model for long-term fracture risk.J Bone Miner Res 2005; 20(4):55I-556.

19. Hernandez CJ, Beaupre GS, Carter DR.A theoretical analysis of the relative influences of peak $B M D$, age-related bone loss and menopause on the development of osteoporosis. Osteoporos Int 2003; I4(I0):843-847. 20. Black DM, Thompson DE, Bauer DC et al. Fracture risk reduction with alendronate in women with osteoporosis: the fracture intervention trial.J Clin Endocrinol Metab 2000;85: 4I |8-4I24.

21.Weycker D, Macarios D, Edelsberg J, Oster G, et al. Compliance with drug therapy for postmenopausal osteoporosis, Osteoporos Int 2006; 17:1645-1652

22. Weycker D, Macarios D, Edelsberg J, Oster G, et al. Compliance with osteoporosis drug therapy and risk of fracture. Osteoporos Int 2007; |8:27|-277.

23.WHO scientific group on the assesment of osteoporosis at primary health care level. Geneva:World Health Organization, 2007.

24. Miller PD, Barlas S, Brenneman Sk, et al.An approach to identifying osteopenic women at increased short-term risk of fracture. Arch Intern Med 2004; 164: I | |3- I I20

25. Klibanski A. NIH Consensus Development Panel on Osteoporosis Prevention, Diagnosis, and Therapy. JAMA 200 I; (6): 785-795

26. Caderette SM, Jaglal SB, Murray T, et al. Evaluation of decision rules for referring women for bone densitometry by dual-energy $\mathrm{x}$-ray absorptiometry.JAMA 200I;286(I): 57-63.

27. Schousboe JT, Bauer DC, Nyman JA, Kane RL, Melton LJ, Ensrud KE. Potential for bone turnover markers to cost-effectively identify and select post-menopausal osteopenic women at high risk of fracture for bisphosphonate therapy. Osteoporos Int 2007; 18:20I-210 28. Blake GM, Fogelman I. Role of Dual-Energy X-Ray Absorptiometry in the Diagnosis and Treatment of Osteoporosis. Journal of Clinical Densitometry 2007;(10) I:102-110.

29. Arlot. Trabecular and Endocortical Bone Remodeling in

Postmenopausal Osteoporosis: Comparison with Normal Postmenopausal Women. Osteoporosis Int 1990; 1:41-49.

30. Meunier PJ, Boivin G. Bone mineral density reflects bone mass but also the degree of mineralisation of bone: therapeutic implications. Bone 1997;21:373-377

3I. Boivin G, Meunier PJ.The degree of mineralization of bone tissue measured by computerized quantitative contact microradiography. Calcif. Tissue Int 2002;70:503-5II.

32. Cameron JR, Sorenson JA. Measurement of Bone Mineral in vivo:An improved method. Science 1963; I 42:230-232. 
33. Mazzes RB, Peppler WW, Chestnut ChD. Total body bone mineral and lean body mass by dual photon absorptiometry II. Comparison with total body calcium by neutron activation analysis. Calcif Tissue Int I982; 3:36I-363.

34.Whaner HW, Dunn WL, Brown MC. Comparison of dual energy $\mathrm{X}$ ray absorptiometry and photon absorptiometry for bone mineral measurement of lumbar spine. Mayo Clin Proc 1988; 63: 1075-1084. 35. Lindsay R, Cosman F, Zhou H, Bostrom MP, Shen VW, Cruz JD, et al. A novel Tetracycline Labelling Schedule for Longitudinal Evaluation of the Short-Term Effects of Anabolic Therapy With a Single lliac Crest Bone Biopsy : Early Actions of Teriparatide.J Bone Miner Res 2006;2I(3):366-373. 36. Odgaard A, Gundersen HJG. Quantification of connectivity in cancellous bone, with special emphasis on 3-D reconstruction. Bone 1993; 14:173-182

37. Odgaard A. Three-Dimensional methods for Quantification of Cancellous Bone Architecture. Bone 1997;20,(4) 315-328.

38. Seeman E. Bone quality. Osteoporos Int 2003; I4(Suppl 5):S3-S7.

39. Seeman E. Osteocytes-martyrs for integrity of bone strength. Osteoporos Int 2006; 17:1443-1448.

40. Seeman E. The periosteum-a surface for all seasons. Osteoporos Int 2007;8:123-128.

41. Jee WSS, Tian XY, Setterberg RB. Cancellous bone minimodeling-based formation:A Frost, Takahashi Legacy.J Musculoskelet Neuronal Interact 2007;7(3):232-239.

42. Kristina Åkesson K. New approaches to pharmacological treatment of osteoporosis.Bull World Health Organ 2003;81:657-664.

43. Riggs BL, Parfitt AM. Perspective; Drugs Used to Treat Osteoporosis: The Critical Need for a Uniform Nomenclature Based on Their Action on Bone Remodeling,J Bone Miner Res 2005;20: 177-I84.

44. Kleerekoper M. Osteoporosis prevention and therapy: preserving and building strength through bone quality Osteoporos Int (2006); 17: 1707- 7 1 5 . 45. Gillespie LD, Gillespie W], Robertson MC, Lamb SE, Cumming RG, Rowe $\mathrm{BH}$. Interventions for preventing falls in elderly people. Cochrane Database of Systematic Reviews. Accession Number:00075320100000000-00635; 4, 2007.

46. Jackson RD, LaCroix A, Gass M,Wallace RB, et.al. Calcium plus Vitamin D Supplementation and the Risk of Fracture. NEJM 2006;344(7):667-683. 47. Avenell A, Handoll HHG. Nutritional supplementation for hip fracture aftercare in older people. Cochrane Database of Systematic Reviews. Accession Number:00075320-100000000-01344; 4, 2007

48. Milne AC, Potter J,Avenell A. Protein and energy supplementation in elderly people at risk from malnutrition. Cochrane Database of Systematic Reviews.Accession Number:00075320-100000000-02297;4, 2007. 49. Avenell A, Gillespie WJ, Gillespie LD, O'Connell DL.Vitamin D and vitamin $D$ analogues for preventing fractures associated with involutional and post-menopausal osteoporosis. Cochrane Database of Systematic Reviews.Accession Number 00075320-100000000-00018; 4, 2007. 50. Meunier PJ, Boivin G. Bone mineral density reflects bone mass but also the degree of mineralisation of bone: therapeutic implications. Bone 1997;21:373-377.

5I. Boivin G, Meunier PJ.The degree of mineralisation of bone tissue measured by computerized quantitative contact microradiography. Calcif Tissue Int 2002;70:503-5II.

52. Holick MF, Siris ES, Binkley N, Beard MK, Khan A, Katzer JT, et al. Prevalence of Vitamin D Inadequacy among Postmenopausal North American Women Receiving Osteoporosis Therapy.J Clin Endocrinol Metab 2005;90: 3215-3224.

53. Degens H.Age-related skeletal muscle dysfunction: causes and mechanisms.J Musculo skelet Neuronal Interact 2007;7(3):246-252. 54.Arlot M, Meunier PJ, Boivin G, Haddock L, Tamayo J, Correa-Rotter $R$, et al. Differential effects of teriparatide and alendronate on bone remodeling in postmenopausal women assessed by histomorphometric parameters.J Bone Miner Res 2005; 20: I244-I 253.
55. Parfitt AM. The coupling of bone formation to bone resorption: a critical analysis of the concept and its relevance to the pathogenesis of osteoporosis. Metab Bone Dis Relat Res 1982; 4: I-6.

56. Feldstein AC,Vollmer WM, Smith DH, Petrick A, Schneider J, Glauber $\mathrm{H}$, et al.An outreach program improved osteoporosis management after a fracture.J Bone Min Res 2007; 22: S508.

57.Walsh MC, Hunter GR, Livingstone MB.Sarcopenia in premenopausal and postmenopausal women with osteopenia, osteoporosis and normal bone mineral density. Osteoporos Int 2006; 17:61-67.

58. U.S. Preventive Services Task Force. Hormone Therapy for the Prevention of Chronic Conditions in Postmenopausal Women: Recommendations from the U.S. Preventive Services Task Force.Ann Intern Med 2005; | 42:855-860.

59. Ettinger B, Black DM, Mitlak BH, Knickerbocker RK, Nickelsen T, Genant HK, et al. Reduction of vertebral fracture risk in postmenopausal women with osteoporosis treated with raloxifene:results from a 3-year randomized clinical trial. Multiple Outcomes of Raloxifene Evaluation (MORE). JAMA 1999; 282: 637-645.

60. National Institute for Clinical Excellence (NICE) Bisphosphonates (alendronate, etidronate, risedronate), selective oestrogen receptor modulato rs (raloxifene) and parathyroid hormone (teriparatide) for the secondary prevention of osteoporotic fragility fractures in postmenopausal women. London; NICE Technology Appraisal 87, 2005. 61. Liberman UA. Hip and non-spine fracture risk reductions differ among antiresortive agents: evidence from randomized controlled trial. Int J Clin Pract 2006;60(II):I394-1400.

62. Bianchi G, Sambrook P. Oral nitrogen-containing bisphosphonates: a systematic review of randomized clinical trials and vertebral fractures. Curr Med Res Opin 2008;Aug 8.

63. Papapoulos SE, Quandt SA, Liberman UA. Meta-analysis if the eficacy of alendronate for the prevention of hip fractures in postmenopausal women. Osteoporos Int 2005; 16: 468-474.

64. Mortensen L, Charles P, Bekker PJ, Digennaro J, Johnston CC. Risedronate increases bone mass in an early postmenopausal population: two years of treatment plus one year of follow up. J Clin Endocrinol Metab 1998;83:396-402.

65. Reginster JY, Minne HW, Sorensen OH. Randomizad trial of the effects of risendonate on vertebral fractures in women with established postmenopausal osteoporosis. Osteoporos Int 2000; I 1:83-91.

66. McClung MR, Geusens P, Millar PD, Zippel H, Bensen WG, Roux C, et al. Effect of risedronate on the risk of hip fracture in elderly women. Hip Intervention Program Study Goup. N Engl J Med 2001;344:333-340. 67. Cranney A,Adachi JD, Guyatt G, Papaioannou A, Robinson VA, Shea BJ, et al. Risedronate for the prevention and treatment of postmenopausal osteoporosis. Cochrane Database of Systematic Reviews. Accession Number:00075320-100000000-03532;4, 2007

68. Schreck B, Serota A, Helfet D, Peterson MGE, Sinha N, Lane JM. Vitamin $D$ Deficiency: a common occurrence in both high and low energy fractures.J Bone Min Res 2007:22: S48I.

69. Chesnut CH III, Skag A, Christiansen C. Effects of oral ibandronate administered daily or intermittently on fracture risk in postmenopausal osteoporosis. J Bone Miner Res 2004; 19:124I-1249.

70. Register JY,Adami S, et.al. Efficacy and tolerability of one-monthy oral ibandronate in postmenopausal osteoporosis: 2 year results from the MOBILE study. Annals of the Rheumatic Diseases 2006: 65:654-66I. 7I. United States Food and Drug Administration, Center for Drug Evaluation and Research. Application Number 21-455. Bonviva Medical Review. (Accessed May 27, 2006). Available at: http://www.fda.gov/cder/foi/ nda/2003/ 2I-455_Bonviva_medr:PI.pdf

72. Lyles K, Colon-Emeric C, Magaziner J,Adachi J, Pieper C, HyldstrupL, et al. Efficacy and safety of zolendronic acid $5 \mathrm{mg}$.in preventing fractures in men and women with prevalent hip fracture: the HORIZON recurrent fracture trial.J Bone and Min Res 2007;22:SI6. 
73. Bolland MJ, Grey A, Horne A, Briggs S, Thomas M, Ellis-Pegler R, et al. The effects of intravenous zolendronate on bone turnover and bone density persist for at least 24 months. J Bone Min res 2007:22:S 325. 74. Hagenau T, Vest R, Gissel T, Poulsen CS, Erlandsen M, Mosekilde L, et al. Global Vitamin levels in realtion to age, gender, etnicity and latitude: an ecologic metaregression analysis. J Bone Min Res 2007;22:S40I.

75. Clark P, Carlos F, Barrera C, Guzman J, Maetzel A, Lavielle P, et al. Direct costs of osteoporosis and hip fracture: an analysis for the Mexican healthcare system. Osteoporos Int 2008;19(3):269-276.

76. Aurbach GD. Isolation of parathyroid hormone after extraction with phenol.J Biol Chem 1959; 234:3179.

77. Alexandre C, Chappard D, Caulin F, Bertrand A, Palle S, Riffat G. Effects of a one-year administration of phosphate and intermittent calcitonin on bone-forming and bone-resorbing cells in involutional osteoporosis: a histomorphometric study. Calcif Tissue Int 1988;42:345-350.

78. Neer RM, Rnaud CD, Zanchetta JR, Prince R, Gaich GA, Reginster $\mathrm{JY}$, et al. Effect of parathyroid hormone on fractures and bone mineral density in postmenopausal women with osteoporosis. N Engl J Med 200I;344: I434-I44I.

79. Black DM, Greenspan SL, Enrud KE, Palermo L, McGowan JA, Lang $\mathrm{TF}$, et al.The effects of parathyroid hormone and alendronate alone or in combination in postmenopausal osteoporosis. N Engl J Med 2003;349:1207-1215.
80. Marie P. Mechanisms of action and therapeutic potential of strontium in bone- Calcif Tissue Int 2001;69(3):121-129.

81. Marie PJ. Optimizing bone metabolism in osteoporosis: insight into the pharmacologic profile of estrontium renalate. Osteoporosis Int 2003; I4: S9-SI2.

82. Meunier PJ.The effects of Strontium Ranelate on the risk of vertebral fracture in women with postmenopausal osteoporosis. N Engl J Med 2004;350(5):459-468.

83. O'Donnell S, Cranney A, Wells GA, Adachi JD, Reginster JY. Strontium ranelate for preventing and treating postmenopausal osteoporosis. Cochrane Database of Systematic Reviews. Accession Number: 00075320-100000000-04300; 4, 2007.

84. Matkovic V, Kostial K, Simonovic I. Bone status and fracture rates in two regions of Yugoslavia. Am J Clin Nutr 1979;32:540-549.

85. Miller P, Bolognese M, Lewiecky EM, McClung M, Ding B,Liu Y, et al. Effect of denosumab on bone mineral density and bone turnover markers: 48-month results. J Bone Min Res 2007:22: S58.

86. Westover AJ, Chagnovich D, Long MW. Dual action cathepsin K inhibitors: modulation of human osteoclast function.J Bone Min Res 2007:22:5204.

87. KR62980 a novel compound, enhances bone formation through promoting osteoblastogenesis and inhibiting osteoclastogenesis.J Bone Min Res 2007:22;S204. 